The Dahl's Law And The Luyia Law In Luyia Dialects 


\title{
Dahl's Law and The Luyia Law in Luyia Dialects Spoken in Western Kenya
}

\author{
Lynn Kisembe \\ All Nations University, Koforidua - Ghana
}

\begin{abstract}
The Luyia people identify themselves as a group that uses the language Luyia. However, there are significant linguistic differences among the speakers, a situation described as the existence of Luyia dialects. The sound realizations differ in each variety, a condition that the Luyia speakers themselves are aware of. Hence they talk of speakers of other varieties as having a characteristic articulation of a particular sound. These differences are a result of the way in which each Luyia variety has developed from the proto-language, ProtoLuyia. The Luyia varieties show a high degree of correspondence at all levels, but differ one from another to the extent that a separate treatment of each variety could be justifiable. At the phonological level for instance, a majority of the phonological correspondences appear to be regular and predictable. However, there exist some sound differences that are quite distinct because of processes such as Bantu Spirantization ${ }^{1}$, Dahl's $\mathrm{Law}^{2}$ and the Luyia $\mathrm{Law}^{3}$, which operate differently. Therefore, attempts at a rigid classification of Luyia varieties based on the status of these processes are likely to fail. The results indicate that Bukusu, Kabras, Wanga, Xaayo, Marachi, Saamia and Kisa attest Bantu Spirantization. These varieties represent the northern and central varieties of the geographical classification of Luyia varieties. Dahl's Law occurred across Luyia, but its results are complicated by the later application of the Luyia Law that obscures the results of Dahl's Law. The trigger consonants for Dahl's Law in Luyia include $\mathrm{p}$, $\mathrm{t}$, and $\mathrm{k}$, which affect $\mathrm{p}, \mathrm{t}$, and $\mathrm{k}$ as target consonants in Logooli, and affect only $\mathrm{t}$ in Xaayo, Marachi and Saamia. The Luyia Law is attested across Luyia except in Logooli where it is not attested and in Saamia where it is not uniform. Saamia shows the Luyia Law for *p, *k and ${ }^{*}$, but not for *t.
\end{abstract}

\section{HISTORICAL BACKGROUND OF LUYIA}

The Luyia are a group of some four million people (Grimes 2000) residing in western Kenya on the Kenya-Uganda border, adjacent to the (non-Bantu) Kalenjin and Luo to the east and south, respectively, and whose northern limit is Mount Elgon. 
Maps 1 and 2 show the geographical location of Luyia within Kenya and the Luyia varieties spoken in various districts of Western Province respectively. The Luyia form the second largest linguistic group in Kenya. The Luyia people identify themselves as the group that uses the language Luyia. There are significant linguistic differences among the speakers, a situation described as the existence of Luyia dialects. These differences are as a result of the way in which each dialect has developed from Proto-Luyia. The number of dialects that form Luyia is dependent upon the way they are counted, since there is no generally accepted method for distinguishing between dialect and language. Because of this, I choose to use varieties as a substitute for dialects. Luyia varieties number either sixteen or seventeen within an area of over 3000 square miles, (Itebete 1974).

Three kinds of approaches have been used in determining the genetic relations among Luyia varieties. The first can be seen in Guthrie (1967), who uses a set of criteria not purely linguistic and divides the Bantu area into 15 zones, with each zone divided into a variable number of groups, for example, A10, E20, etc. Guthrie has the group Masaaba-Luyia under zone E30. Masaaba-Luyia divides into Gisu, and Kisu in Uganda, and Bukusu, Hanga, Tsotso, Nyore, Saamia and Nyuli in Kenya. The second approach involves lexicostatistical analysis, which (Nurse and Philippson 1980) evaluates the degree of similarity between the Bantu languages of East Africa, by comparing a set of vocabulary. They group the languages into immediate groups, and where possible, into larger groups. Nurse and Philippson (1980) combined Guthrie's E30 (Luyia) and E41 (Logooli), forming a larger group than previously. They then subdivided Luyia into northern and southern dialect areas. The northern area consisting of Masaaba-Saamia and the southern area Logooli-Isuxa.

The third approach characterizes the whole group on the basis of a small number of sound correspondences and some shared inflectional morphology (Angogo 1980, Bennett 1973, and Mould 1981). Each of these authors uses different criteria in analysing Luyia. Angogo (1980) compares the structural aspects of the Luyia varieties, using phonology, morphology, syntax and lexicon/semantics. Based on this, she groups the dialects into three, namely northern Luyia (centered around Bukusu), central Luyia (centered around Wanga) and southern Luyia, with Logooli being the locus. Bennett (1973) uses phonological isoglosses, and postulates a tripartite division of the language family he referred to as North-East Victoria Bantu (NEV) which includes northern (Gisu, Masaaba and Bukusu), southern (Idaxo, Isuxa and Logooli), and central, which comprises all the intervening dialects of Xaayo, Saamia, Nyole, Gwe, Nyuli, Hanga, Nyala and Tsotso. Mould (1981) examines Luyia within the context of Bantu languages of the western section of East Africa. He assumes a geographical subdivision of Luyia into northern, eastern, southern, western and central Luyia. The scope of his work covers five representative dialects from four subdivisions, (excluding the eastern sub-division), because his claim is that eastern Luyia dialects resemble those of central and northern. In his discussion, Mould 
distinguishes between Greater Luyia (Luyia and Logooli) and Luyia (rest of Luyia dialects). Mould uses lexicostatistical (200 word list) and phonological (sound correspondences, consonant internal reconstruction, Bantu Spirantization and the 7-to-5 vowel merger, spirant devoicing, the Luyia Law and nasal cluster rules) and morphological (tense/aspect system) data in describing Greater Luyia. The initial focus is on Greater Luyia as a group, followed by a discussion on the group's relationships with its immediate neighbors. Mould concludes that Greater Luyia is justified in so far as nasal cluster rules are concerned, and that Bantu Spirantization distinguishes northern and central Luyia from the rest of Luyia.

\section{OBJECTIVE}

Linguists have long puzzled over the dialect divisions within Luyia and especially over the concept of-north versus south Luyia. Why should varieties, perceived to be mutually intelligible and viewed by their speakers as belonging to one group, be divided by their different treatment of certain phonological phenomena (Bantu Spirantization, seven versus five vowels), which elsewhere only divide major Bantu subgroups from their neighbors? The question that is still left unanswered is whether the overall varieties grouped as Luyia should in fact be so classified, or should they be classified differently. The goal of this study is to determine boundaries between Luyia varieties that are primarily motivated by linguistic factors with the hope of contributing knowledge to the linguistic classification of Luyia varieties for the creation of a linguistic dialect map of Luyia. The main focus of this paper is to show the linguistic variation that exists in Luyia. These varieties are examined using two phonological innovations affecting consonants, namely Dahl's Law and the Luyia Law.

\section{Theoretical/Conceptual framework}

This work is-partly based on Chambers and Trudgill's (1980) space models of diffusion. Their discussion includes lexical diffusion as an explanation for incomplete sound changes. The models of diffusion discussed by Chambers and Trudgill are incorporated with a simple taxonomic model that involves drawing of isoglosses in maps for each relevant feature. A look at how the processes operate within Luyia reveals a pattern which indicates the existence of a focal area from which the innovations originate and in which the process is regular.

The Luyia continuum is represented as below:

Northern

$$
\begin{array}{lll} 
& \text { Southern } \\
\text { Saamia } & \text { Idaxo } & \text { Loogoli }
\end{array}
$$

Bukusu Wanga Saamia Idaxo Loogoli

Dahl's Law for instance, has its focal area within southern Luyia where the process is regular, as in the neighboring control language Gusii (E42), and 
leaves only traces as it spreads through central Luyia to northern Luyia, and the neighboring control language Ganda (E15), where Dahl's Law is not attested. Dahl's Law results in Luyia being divided into three categories. Category A: Logooli, Category B, Xaayo, Marachi and Saamia: and Category C, Bukusu, Kabras, Wanga, Nyala B, Kisa, Idaxo, Isuxa and Tiriki as shown in Map 1: Dahl's Law in Luyia.

A single line is drawn to separate the southern Luyia region where active Dahl's Law is attested and another line drawn to separate the central Luyia region where both active Dahl's Law and traces occur, and the remaining region showing varieties with Dahl's Law traces.

The Luyia Law occurs in all varieties of Luyia except Logooli (Bennett 1973), and in Saamia, where it is not uniform. This is represented by a single line that separates the region occupied by Logooli speakers, where the Luyia Law does not occur, from the rest of the Luyia geographical region, where it occurs.

The phonological innovations spread through the transition area in which the spread loses its generality (because some sound changes are incomplete), towards the relic area which is not affected by the spread.

In a geographical dialect continuum, dialects on the outer edges of the geographical area may not be mutually intelligible, but they will be linked by a chain of mutual intelligibility (Chambers and Trudgill 1980). The further one gets from the starting point, the larger the differences will become, if the distance involved is large enough. Thus, finding a particular isogloss delimiting areas in more than one part of the survey region with no continuity is a possibility (Chambers and Trudgill 1980). Chambers and Trudgill (1980) further mention that such linguistic features that exist in two or more parts of the region are separated from one another by an area in which a different feature occurs. Such a pattern, they remark, indicates a late stage in the displacement of a formerly widespread linguistic feature by an innovation, because in the earlier times the feature which occurs in isolated areas was also found in the in-between areas. These types of areal features, they state, are as a result of linguistic innovation originating in one dialect and then spreading to neighboring varieties, regardless of the language boundaries, presumably through the medium of bilingual individuals.

\section{Rationale of this work}

No good linguistic investigation of Luyia varieties has ever been published. This statement is supported by Angogo (1980:11:)

The fact that the local dialect divisions also roughly coincide with the locations is to be expected in the light of the composition of the Abaluhyia clans, but from a linguistic point of view it means that we still lack an accurate dialect map of Buluhyia. The majority of phonological correspondences among the Luyia dialects appear to be regular and predictable, though no systematic study of them has yet been made. 
A more recent call for research focusing on Luyia varieties is seen in Nurse's (1999:32) suggestion for future work examining the overlap between linguistic and ethnic boundaries. Nurse poses the question:What happened on the eastern side of Victoria, where the Luyia speak of themselves as one group, but their dialect area is split by what linguists would consider major differences?

This paper therefore, aims at contributing knowledge towards an analysis of Luyia varieties from a linguistic point of view.

\section{SCOPE}

The overall scope is primarily a linguistic one, analyzing Luyia varieties in question using two diachronic phonological processes, Dahl's Law and the Luyia Law. Although Luyia is also spoken by groups of people who live on the Uganda side of the border, the scope of this research is limited to varieties spoken on the Kenyan side. The varieties covered in this study are Logooli, Idaxo, Isuxa, Tiriki and Kisa (southern Luyia), Bukusu and Kabras (northern Luyia), and Saamia, Wanga, Xaayo, Marachi and Nyala B (central Luyia).

\section{METHODOLOGY}

This study focuses on Dahl's Law and the Luyia Law. These processes are briefly described in this section but each will be dealt with in greater detail. Why phonological analysis? Despite the fact that Bantu languages are related and exhibit common structural features at the phonological level, dialect differences are nevertheless considerable. A number of differences are the result of Dahl's Law and the Luyia Law, which operated differently in different dialects.

\section{Dahl's Law}

As defined earlier, Dahl's Law is a dissimilation process which in its most general form voices the first of the two voiceless obstruents that are always separated by an intervening vowel (Bennett 1976:133). Bennett points out that Dahl's Law manifestations vary from language to language. For instance, within East Africa, the process is active in some languages, while in others there are traces, and in a few languages (such as Swahili) there appear to be none (Nurse 1979:118). Bennett (1976) claims that even in those languages where the process occurs regularly, it varies considerably in both form and range of application. Dahl's Law works in a variety of environments, from restrictions to a wide range of application. For instance, in Luyia, it does not apply except within a morpheme; in other Bantu languages such as Kikuyu, elements prefixed to the morpheme are affected, while in Gusii, both prefixes and morpheme final consonants followed by suffixes are affected (Bennett 
1976:113). Restrictions on the occurrence of Dahl's Law are imposed not only by the position within the word or morpheme of the two consonants, but also the range of consonants which may condition or be conditioned.

\section{The Luyia Law}

A number of Luyia varieties show a group of rules involving a consonant shift, similar to that of Grimm's $\mathrm{Law}^{4}$ in Germanic languages. This phenomenon is subsequently referred to as the Luyia Law. The Luyia Law involves the devoicing of voiced stops and the Spirantization of voiceless stops (Mould 1981:194). The two Luyia Law processes will be treated separately. The following examples illustrate the Luyia Law. The segments affected are underlined. The Proto-Bantu form *-kuba >-xupa 'hit', *-guda > $-k u l a$ 'buy'. The voiced stops $\mathrm{b}$ and $\mathrm{g}$ devoice to $\mathrm{p}$ and $\mathrm{k}$ respectively. The Spirantization of voiceless stops is seen in the example, ${ }^{*}$-kono $>-x o n o$ 'arm'(Mould 1981:194).

Luyia Law Spirantization and Bantu Spirantization are different in several ways. Whereas Bantu Spirantization was only triggered by firstdegree vowels $* \mathrm{i}$ and $* \mathrm{u}$, the Luyia Law occurred in any remaining intervocalic environment. And whereas Bantu Spirantization affected all nonnasal consonants, the Luyia Law only affects voiceless $* \mathrm{p}, \mathrm{t}$, $\mathrm{k}$ that spirantizes to $h, r$, and $x$ respectively. Examples illustrating the Luyia Law drawn from Bukusu and Wanga are given in (1) below.

\section{(1) The Luyia Law in Bukusu and Wanga}

$\begin{array}{llll}\text { Proto-Bantu } & \text { Bukusu } & \text { Wanga } & \text { Gloss } \\ \text { *-teg- } & \text { reka } & \text { reka } & \text { set a trap } \\ \text { *teek } & \text { deexa } & \text { teexa } & \text { cook }\end{array}$

The second line in (1) assumes *teek $>$ deex ->teex. The PB *t undergoes Dahl's Law to d, which then devoices to $\mathbf{t}$.

\section{Data collection}

The linguistic data presented here are drawn from twelve Luyia varieties, which help establish the various groups into which these varieties may be categorized from an objective point of view. A questionnaire was used for data collection. This questionnaire comprised a list of 250 words for each variety of Luyia under study. 


\section{The 250 word list}

The 250 word list was derived from Guthrie's (1967) reconstructed Common Bantu lexical items, Masele's (2001) word list used for eliciting lexical items for a discussion of Dahl's Law in three Bantu languages spoken in Tanzania, Bickmore's (1998) data used in examining Dahl's Law in Gusii, Hyman (1967) for data in Ganda, and Grimes' (2000) data found on the Summer Institute of Linguistics' web page. The list contained standard vocabulary widely known to speakers of all Luyia varieties. Care was taken such that words elicited were unambiguous and reliable. That is, the list consisted of body parts, names of common animals and plants, household implements commonly used, natural phenomena, and verbs referring to clear functions. The list was translated into English and is attached as the Appendix.

\section{The interview session}

Interview sessions were carried out where the informant responded to the items on the list in her/his own variety. During the interview, two copies of the lists were used. The interviewer filled one list, while the informant followed along in the second. The list was read out to the informant as she/he followed along and the elicitation was tape-recorded. Questionnaires were filled as the interview progressed. The tape-recorded information was later transcribed.

\section{The informants}

The informants selected fell within the age category of 30-60 years and were trilingual in their ethnic language, Swahili, and English. The purpose of drawing upon this sample was to eliminate use of interpreters. Target informants were university students and professors, as well as employees within the government and private sector in Nairobi. Later on the older generation of speakers in Luyia land served as key informants as a means to validate the collected data. Overall twenty-four respondents participated in this study with two informants selected for each of the twelve varieties of Luyia under investigation. The variety I speak is Bukusu.

\section{Data analysis}

The following are some of the questions that were used as a guiding tool in the data analysis process.

(a) Identification of variation patterns of Dahl's Law, and the Luyia Law within the various varieties. Resulting patterns are used as diagnostic criteria in the classification.

(b) While some changes may apply only to particular segments, others may apply entirely to natural classes of segments with each correspondent change noted. For example in Logooli, Dahl's Law affects p, t and k (*-pita > 
Bita, *-tap- $>$ daha, *-kut- $>$ guta), while in Saamia $t$ is the only affected consonant (*-tap- $>$ daya), and not $\mathrm{k}$ as seen in the example *-kųt- > kuta.

Dahl's Law analyzed

Dahl's Law is found in a number of Bantu languages in East Africa, for example Nyamwezi, (Bennett 1976), Kikuyu, (Davy and Nurse 1982), Gusii, (Bickmore 1998) and Sukuma, (Masele 2002). Bennett (ibid) notes that within East Africa, the further the west the language is geographically, the stronger its form of Dahl's Law. Thus, for languages near Lake Victoria, one finds forms of Dahl's Law which are regular.

Bennett (1976) mentions that in those languages where Dahl's Law is found, its existence is limited. He states further that in those languages where Dahl's Law is regular, it varies in both form and range of application. Form refers to the position of the affected consonant in the word, while range refers to the consonants that are conditioned (target consonants) or may condition (trigger consonants) the process. With respect to form, Dahl's Law works in a variety of environments. For instance, in Luyia, it does not apply except within a root (Bennett 1976, Davy and Nurse 1982). In Bantu languages such as Kikuyu, elements prefixed to the root are affected (Davy and Nurse 1982), while in Gusii both prefixes and root final consonants followed by suffixes are affected (Bennett 1976, Bickmore 1998).

Restrictions on the occurrence of Dahl's Law in different languages are imposed not only by the position of the two consonants within the word or morpheme, but also the range of consonants which may condition or be conditioned. In Kikuyu, for example, Bennett (1976) points out that the only consonant affected is $\mathrm{k}$, with the conditioning consonants being $\mathrm{k}, \mathrm{c}, \mathrm{t}$, and $\theta$ (Davy and Nurse 1982). Within Luyia, the consonants affected are p, t, k, while those conditioning the shift include $\mathrm{p}, \mathrm{t}, \mathrm{k}$ (Bennett 1976). Davy and Nurse (1982) mention that traces of one or more of the affected consonants $p$, $\mathrm{t}, \mathrm{k}$ undergoing mutation before a voiceless obstruent exist in Luyia, and this can be seen by comparing contemporary stems with their Proto-Bantu reconstructions.

Within East Africa, the process is active in some languages, while in others there are traces and in a few languages (such as Swahili) there appear to be none (Nurse 1979). Previous findings reveal that some Luyia varieties attested active Dahl's Law, for example Logooli and Saamia, while other varieties such as Bukusu, Wanga and Idaxo show traces of Dahl's Law (Mould 1981). Below is a sketch showing varieties based on geographical subdivision that attest active Dahl's Law and those that exhibit traces in Luyia according to Mould (1981).

Traces are based on the hypothesis that the whole of Luyia underwent DL (Bennett 1976). However, DL results in Luyia have been obscured by the Luyia Law that devoices the voiced stops which result from DL and spirantizes the voiceless stops (Mould 1981). 
Dahl's Law in Bukusu, Wanga, Idaxo, Saamia and Logooli.

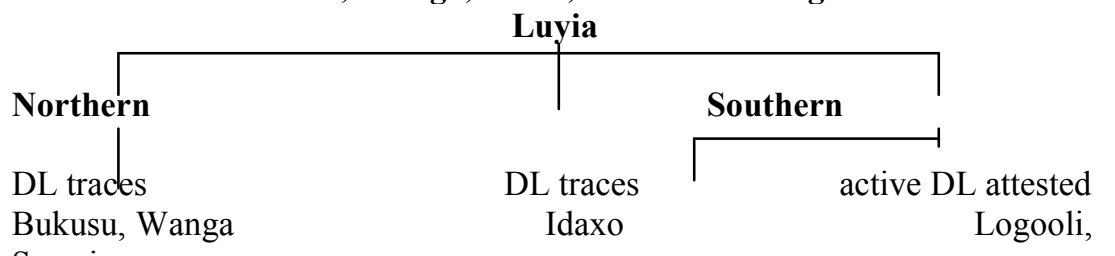

Saamia

Bennett (1976) notes that Luyia underwent a general form of Dahl's Law, but because of phonetic shifts, such as the Luyia Law ${ }^{5}$, that Luyia has undergone, the working of Dahl's Law has been complicated. The following section examines Dahl's Law in the twelve Luyia varieties in question.

\section{Linguistic results of Dahl's Law}

Based on the available data, it is quite clear that Luyia attests Dahl's Law. From the Appendix, only those words containing consecutive syllables with voiceless stop consonants were used in analyzing Dahl's Law. Out of the initial 250 word list, only 135 forms were found useful for the analysis of Dahl's Law and the Luyia Law, and a total of twenty six words found in lines $2,5,3,7,9,10,14,15,23,29,31,43,59,64,66,77,78,92,94,95,96,97$, 120, 124 (a), 126, 127, were useful in identifying Dahl's Law in Luyia.

In explaining Dahl's Law, we distinguish between active Dahl's Law and Dahl's Law traces (Dahl's Law obscured by the occurrence of the Luyia Law). Active Dahl's Law is seen in varieties such as Logooli, Saamia, Marachi and Xaayo, where ${ }^{*} \mathrm{p}>\beta,{ }^{*}>\mathrm{d},{ }^{*} \mathrm{k}>\mathrm{g}$, while varieties such as Tiriki, Isuxa, Idaxo, Kisa, Nyala B, Wanga, Kabras and Bukusu, which may seem not to undergo Dahl's Law as evidenced from the data with no change in $\mathrm{p}, \mathrm{t}$ and $\mathrm{k}\left(*_{\mathrm{t}}>\mathrm{t}\right.$, $* \mathrm{k}>\mathrm{k}$ ), have undergone the process, only that it has been obscured by the occurrence of the Luyia Law. The latter set of varieties exhibit what we are referring to as Dahl's Law traces. This explanation is based on the hypothesis that all of Luyia underwent Dahl's Law (Bennett 1976), and that explanations to sound changes have been complicated by the occurrence of the Luyia Law.

For those varieties that attested active Dahl's Law, our data shows that $p$, $\mathrm{t}$ and $\mathrm{k}$ are the affected consonants, with $\mathrm{p}, \mathrm{t}$, and $\mathrm{k}$ conditioning the shift. The data further reveals that in those varieties where active Dahl's Law takes place, there are a set of varieties that show $t$ as the only affected consonant and this is seen in Xaayo, Saamia and Marachi, and the other set shows all p, $\mathrm{t}$ and $\mathrm{k}$ as the affected consonants with examples drawn from Logooli. I, therefore, group the Luyia varieties into three categories based on Dahl's Law 
results from the evidenced data and subsequently explain the purpose for the grouping. These categories with representative varieties are as follows:

Category A: Logooli "(active DL)

Category B: Xaayo, Marachi and Saamia (both active DL and DL traces)

Category C: Bukusu, Kabras, Wanga, Nyala B, Kisa, Idaxo, Isuxa, and Tiriki (DL traces)

The above-mentioned categories are the result of having examined consonant correspondences involving Dahl's Law between Luyia varieties. Results of Dahl's Law reflexes are seen in Table 1 below, with the control languages Ganda and Gusii on the east and west respectively.

Table 1: Dahl's Law consonant correspondences in

Luyia varieties

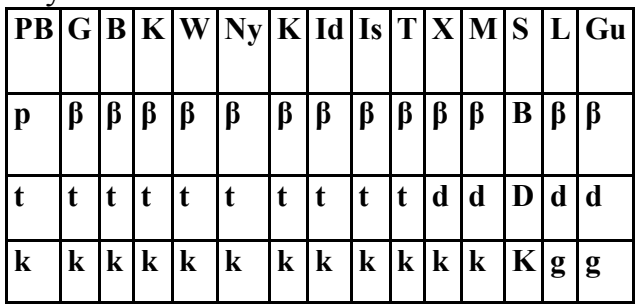

In Table 1 above, $* t / k>t / k$ appear as such across most Luyia (from Bukusu to Tiriki), with ${ }^{*} \mathrm{k}>\mathrm{k}$ running all through from Bukusu to Saamia. These varieties do not seem to change as would be expected of Dahl's Law results because the changes in these varieties get obscured by the later application of the Luyia Law ${ }^{6}$.

Examples used in deriving Table 1 are shown in

Table 2: Examples illustrating the range of consonants affected by and affecting Dahl's law in Luyia varieties (See appendix)

In Table 2 for instance, lines 2, 95, 107 and 64 show $* \mathrm{k}>\mathrm{k}$ for varieties from Bukusu to Saamia showing Dahl's Law traces and the ${ }^{*} \mathrm{k}>\mathrm{g}$ in Logooli for active Dahl's Law.

Examples in (2) below show a comparison of Dahl's Law results in Logooli and Gusii (E41), and (3) show a comparison of Dahl's Law results in Bukusu and Ganda ${ }^{7}$ (E15) so as to be able to determine the limits of Dahl's Law. Idaxo, Isuxa, Tiriki, Logooli and Gusii have a seven vowel system, while the rest of the Luyia varieties and Ganda have a five vowel system.

Category A has the variety Logooli, that fully attests active Dahl's Law. The trigger consonants in this category include $\mathrm{p}, \mathrm{t}, \mathrm{k}$ while the affected or conditioned consonants are p, t, k. Category B, Xaayo, Marachi and Saamia, 
attest active Dahl's Law, which affects $p$ and $t$ as the conditioned consonants, with $\mathrm{p}, \mathrm{t}, \mathrm{k}$ as the trigger consonants. Gusii has ${ }^{*} \mathrm{k}$

$>\mathrm{g}$ before $* \mathrm{p}$ and $\mathrm{k}$.

From Bukusu all the way to Tiriki (Category C) active Dahl's Law does not seem to be present as evidenced from the available data, ${ }^{*} \mathrm{t}>\mathrm{t},{ }^{*} \mathrm{k}>\mathrm{k}$. There are a few words namely: (*-tako > -daxo 'buttock' and *-teete $>$-deede 'grasshopper') as seen in Idaxo and in the form 'grasshopper' in Tiriki which seem to show active Dahl's Law. Bukusu, Kabras, Wanga, Nyala B and Kisa varieties do not show active Dahl's Law, as stated earlier on because Dahl's Law in these varieties is obscured by the occurrence of the Luyia Law, which takes place after Dahl's Law has occurred. Derivations for Dahl's Law forms for varieties in category $\mathrm{C}$ are dealt with later.

The following section is a discussion on how the Luyia Law works in Luyia.

\section{(2). Comparison of Dahl's Law in Logooli and Gusii.}

\begin{tabular}{|c|c|c|c|c|c|}
\hline Position & Number & Gloss & Proto-Bantu & Logooli & Gusii \\
\hline $\mathrm{p}-\mathrm{p}$ & 126 & wipe excreta & $*$-pipa & - $\beta$ iha & - \\
\hline $\mathrm{p}-\mathrm{t}$ & 96 & pass & *-pita & - $\beta$ ita & -ita \\
\hline $\mathrm{p}-\mathrm{k}$ & 14 & blind person & *-pokų & (mbokų) & omo-uko \\
\hline \multirow[t]{2}{*}{$\mathrm{t}-\mathrm{p}$} & 7 & be blunt & *-tųųp & -dųfu & -tųu \\
\hline & 43 & draw water & $*$-tap & -daha & -taa \\
\hline \multirow[t]{3}{*}{$\mathrm{t}-\mathrm{t}$} & 27 & chop off & *-teet- & - & - \\
\hline & 66 & grasshopper & *-teete & -deede & - \\
\hline & 120 & three & $*_{\text {-tatu }}$ & - & -catu \\
\hline \multirow[t]{3}{*}{$t-k$} & 10 & become split & *-yatik- & -dika & -ata \\
\hline & 21 & buttock & *-tako & -dako & - \\
\hline & 31 & cook & *-teek & -deek & - \\
\hline$k-p$ & 2 & armpit & *-kuap & -gwaha & -kwaa \\
\hline \multirow[t]{2}{*}{$k-t$} & 95 & oil & *-kųta & -gųta & -guta \\
\hline & 107 & satiated & *-kut & -guta & -gota \\
\hline $\mathrm{k}-\mathrm{k}$ & 64 & grandparent & *-kuuku & -guuk & -gokoro \\
\hline
\end{tabular}

(3). Comparison of Dahl's Law in Bukusu and Ganda

\begin{tabular}{|c|c|c|c|c|c|}
\hline Position & Number & Gloss & Proto-Bantu & Bukusu & Ganda \\
\hline $\mathrm{p}-\mathrm{p}$ & 126 & wipe excreta & $*$-pipa & $-\beta$ ia & - \\
\hline $\mathrm{p}-\mathrm{t}$ & 96 & pass & *-pita & $-\beta$ ira & - \\
\hline $\mathrm{p}-\mathrm{k}$ & 14 & blind person & *-poku & $-\beta o f u$ & - \\
\hline \multirow[t]{2}{*}{$t-p$} & 7 & be blunt & *-tųupp- & -fuu & \\
\hline & 43 & draw water & *-tap- & -taa & \\
\hline \multirow[t]{3}{*}{$t-t$} & 27 & chop off & *-teet- & -teeta & - \\
\hline & 66 & Grasshopper & $*$-teete & -teete & - \\
\hline & 120 & Three & $*$-tatu & -taru & -ssatu \\
\hline \multirow[t]{3}{*}{$\mathrm{t}-\mathrm{k}$} & 10 & become split & *-yatik- & -tixa & \\
\hline & 21 & Buttock & *-tako & $-\operatorname{tax} 0$ & -ttako \\
\hline & 31 & Cook & *-teek- & -teek & - \\
\hline$k-p$ & 2 & armpit & *-kuapa & -xwaa & - \\
\hline \multirow[t]{2}{*}{$\mathrm{k}-\mathrm{t}$} & 95 & oil & *-kuta & -fura & -futa \\
\hline & 107 & satiated & *-ikutt- & -kura & -kkusa \\
\hline $\mathrm{k}-\mathrm{k}$ & 64 & grandparent & *-kuuku & -kuuxu & \\
\hline
\end{tabular}




\section{The Luyia Law}

A number of Luyia dialects show a group of rules involving consonant shift similar to that of Grimm's Law in Germanic languages. This phenomenon is subsequently referred to as the Luyia Law. The Luyia Law involves the devoicing of voiced stops $(\mathrm{d}>\mathrm{t}, \mathrm{g}>\mathrm{k})$, and the spirantization of voiceless stops $(p>y / w / h / ø, t>r>r, k>x)$, (Mould 1981). Lenition of *p> $/ / w / h / ø$ is not strictly part of the Luyia Law because it is also attested in many other East African languages (Nurse 1981). The two stages of the Luyia Law will be treated separately as (a) (spirantization) and (b) (devoicing) respectively.

Mould (1981) claims that the genesis and function of sound changes are dependant upon a number of preliminary changes that preceded the Luyia Law chronologically. These preceding changes either set the stage or initiated the beginning of the Luyia Law. Mould argues that a number of events introduced a series of voiced stops. The first of these events is Dahl's Law, which created phonemes such as $\mathrm{d}$ and $\mathrm{g}$ that later on participated in the operation of Luyia Law devoicing.

Luyia Law spirantization is different from Bantu Spirantization in that the trigger in the former involves the environment before the other vowels found within the language, and not the environment before $\dot{k}$ and $u$, which is for Bantu Spirantization. The resulting fricatives from the Luyia Law spirantization are $* \mathrm{p}>\mathrm{y} / \mathrm{w} / \mathrm{h} / \varnothing, *_{\mathrm{t}}>\mathrm{r}>\mathrm{r}$ and $*_{\mathrm{k}}>\mathrm{x}$. The $\mathrm{r}$ is a voiceless retroflex fricative. Table 3(appendix) shows the reflexes of Proto-Bantu stops before non-high vowels i, u, e, o, a. The examples illustrating the results of Table 3: are shown in Table 4 (appendix). These are a few selected examples representing all the Proto-Bantu stops ${ }^{*} \mathrm{p},{ }^{\mathrm{b}}, *_{\mathrm{t}},{ }^{\mathrm{d}} \mathrm{d},{ }_{\mathrm{k}}$, ${ }^{\mathrm{g}} \mathrm{g}$ becoming fricatives and the voiced stop devoicing. The reader should refer to the Appendix for more examples.

\section{Explaining Dahl's Law and the Luyia Law in Luyia}

In this section, I describe each stop consonant $\mathrm{p}, \mathrm{t}, \mathrm{k}$ as a conditioning consonant and show the effects that each has on $\mathrm{p}, \mathrm{t}, \mathrm{k}$ as conditioned consonants in each of the subgroups, namely, categories A, B and C.

\section{* $p$ as a conditioning consonant}

The examples that show * $\mathrm{p}$ as a conditioning consonant are seen in numbers 2,7,43, 124(a), 126 and 127. In Logooli, ${ }^{*} p$ as a conditioning consonant produces $* \mathrm{p}>\beta,{ }^{*} \mathrm{t}>\mathrm{d},{ }^{*} \mathrm{k}>\mathrm{g}$.

In Xaayo, Marachi and Saamia, the results are as follows: ${ }^{*} p>\beta, *_{t}>d$ and ${ }^{*} \mathrm{k}>\mathrm{k}$. It is worth pointing out that the $*_{\mathrm{t}}>\mathrm{d}$ with ${ }^{*} \mathrm{p}$ as a conditioning consonant, occurs only in one example, number 43 and not the other example in number $7 .{ }^{8}$ Therefore, our generalization here is based on only one example. The $\mathrm{k}$ is not affected as a conditioned consonant in these varieties. 
However, examples of $* \mathrm{t}>\mathrm{d}$ are a clear indication of active Dahl's Law. How do we explain the $* k>k$ ? Our explanation is based on the hypotheses that all of Luyia underwent Dahl's Law (Bennett 1976), and that explanations to the sound changes have been complicated by the occurrence of the Luyia Law. So $* \mathrm{k}>\mathrm{k}$ does not mean that Xaayo, Marachi and Saamia did not undergo active Dahl's Law or that the process was not complete. The ${ }^{*} \mathrm{k}>\mathrm{k}$ means that Dahl's Law occurred first followed by the Luyia Law. Thus, the form *kuapa- 'arm pit' in these varieties is derived as in below.

Derivation of the form *-kuapa iii varieties in category B: Xaayo, Marachi and Saamia

\begin{tabular}{ll}
\hline PB & *kuapa \\
\hline DL & -guapa \\
\hline LL-spirantization & -gwaya $(\mathrm{p}>\mathrm{y})$ \\
\hline LL-devoicing & -kwaya \\
\hline Final form & -kwaya \\
\hline
\end{tabular}

In category $\mathrm{C}$, that is, from Bukusu all the way to Tiriki (see sequence in Table 1), ${ }^{*} p$ as a conditioning consonant produces the following results: ${ }^{*} p>$ $\beta,{ }^{*}>\mathrm{t}$ and ${ }^{*} \mathrm{k}>\mathrm{k} / \mathrm{x}$. I use examples that illustrate the variable ordering, where Dahl's Law becomes the Luyia Law. The examples are derived below. In the forms shown and where the Bantu Spirantization environment is met, varieties that attest Bantu Spirantization have the conditioned consonant undergoing Bantu Spirantization. For example, *-tuuup- (no. 7) see footnote 10 for an explanation on the varieties that attest Bantu Spirantization in the derivation shown next. For Bukusu and Kabras, the derivation for *-kuapa follows because after the $\mathrm{k}$ devoices to $\mathrm{k}$, the $\mathrm{k}$ spirantizes to $\mathrm{x}$. The conditioned consonant is the result of Dahl's Law devoicing via the Luyia Law.

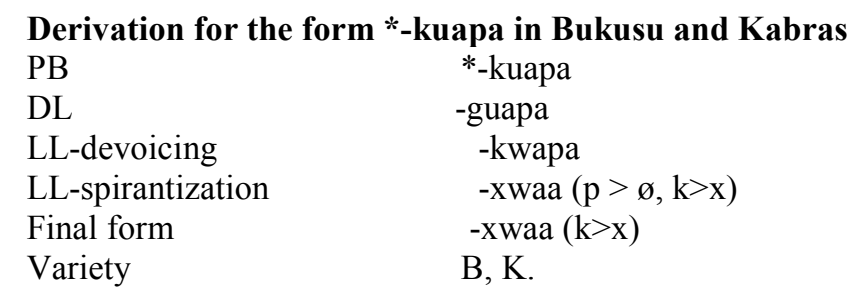

*t as a conditioning consonant

The results of $*_{\mathrm{t}}$ as a conditioning consonant for $\mathrm{p}, \mathrm{t}, \mathrm{k}$, in Logooli are as follows: ${ }^{\mathrm{p}}>\beta, *_{\mathrm{t}}>\mathrm{d}$ and $*_{\mathrm{k}}>\mathrm{g}$. See examples in numbers $27,66,96$ and 120. 
Derivation of the forms *-tuup-, *-tap- and *-kuapa in varieties in category $C$ : Bukusu, Kabras, Wanga, Nyala B, Kisa, Idaxo, Isuxa, Tiriki

\begin{tabular}{llll}
\hline PB & *-tuui $>$ (no. 7) & *-tan- $($ no. 43) & *-kuana (no. 2) \\
\hline DL & -duup- & -dap- & -guapa \\
\hline LL- spirantization & -tuyha- & -taa/taha & -kwaha \\
\hline LL-devoicing $^{10}$ & -tuuha- $^{-}$ & taa/taha & -kwaha \\
\hline Final form & -tuuha- & -taa/taha & -kwaha \\
\hline Variety & Id, Is, T. & & W, NyB, K, Id, Is, T \\
& & B.K. W.NvB.K. Id. Is. T. & \\
& &
\end{tabular}

In Xaayo, Marachi and Saamia, *t as a conditioning consonant results in $*_{\mathrm{p}}>\beta, *_{\mathrm{t}}>\mathrm{d}$ and $*_{\mathrm{k}}>\mathrm{k}$. The $\mathrm{k}$ indicates a Dahl's Law trace, while the $\mathrm{f}$ results from Bantu Spirantization. The derivations for the ${ }^{*} \mathrm{k}>\mathrm{k} / \mathrm{f}$ in Xaayo, Marachi and Saamia are illustrated in (a) and (b) respectively, the former showing $\mathrm{k}$ while the latter showing both $\mathrm{f}$ and $\mathrm{k}$, $\mathrm{f}$ (no 95) resulting from Bantu Spirantization, and k (no 107) which is an exception since the Bantu Spirantization environment is met but the varieties do not undergo any change in this form. The column for Saamia is separated from that Xaayo and Marachi because the Luyia Law is not uniform in Saamia, however, the three varieties are grouped together.

\section{(a) Derivations for *-kuuku in Xaayo, Marachi and Saamia}

\begin{tabular}{ll}
\hline PB & *-kuuku \\
\hline DL & -guuku \\
\hline LL-spirantization & -kuuxu \\
\hline LL-devoicing & -guuxu \\
\hline Final form & -kuuxu \\
\hline Variety & -X, M, S \\
\hline
\end{tabular}

For Xaayo, Marachi and Saamia, with $\mathrm{k}$ as the conditioned consonant, the example in (b) above, shows that the conditioned consonant in these varieties does not undergo the Luyia Law spirantization because the condition for Bantu Spirantization is met. However, the conditioning consonant $*_{t}$ undergoes the Luyia Law spirantization in only Xaayo and Marachi, but this sound change does not occur in Saamia (one of the examples showing how the Luyia Law is not uniform in Saamia). The $\mathbf{f}$ sound in the form *-kuta-, is a result of Bantu Spirantization which is triggered by the adjacent high volume. 
(b) Derivations for *-kut- in Xaayo, Marachi and Saamia

\begin{tabular}{ccc}
\hline & $*$-kųta (no. 95) & $*$-kųta- \\
\hline Bantu Spirantization & -futa & -fųta \\
\hline LL-spirantization & -furra $(\mathrm{t}>\mathrm{r})$ & - \\
\hline Final form & -fura & -futa \\
\hline Variety & -X,M & $\mathrm{S}$ \\
\hline
\end{tabular}

The results for Bukusu, Kabras, Wanga, NyalaB, Kisa, Idaxo, Isuxa and Tiriki, show $* \mathrm{p}>\beta,{ }_{\mathrm{t}}>\mathrm{t}$ and $* \mathrm{k}>\mathrm{k}$. The derivations for these examples are shown in (c). Note that some varieties in category $\mathrm{C}$ may not be included in their respective slots in (c) during the derivation because of the differences in some sound changes. This does not however, mean that they form another subgroup. It is purely meant for explanatory purposes which are detailed in the footnote, because the entire subgroup is viewed as one.

(c). Derivation for the forms *-teet-, *-teete, *-tatu, *- kijta, *-kut in Category C: Bukusu, Kabras, Wanga, NyalaB, Kisa, Idaxo, Isuxa, Tiriki

\begin{tabular}{llllll}
\hline PB & $*$-teet- & -teete & $*$ tatu & $*$-kuta & $*$-kut- \\
BS & - & - & - & -futa & - \\
DL & -deet- & -deete & -datu & - & -gut- \\
LL-spirantization & - & - & -daru $(\mathrm{t}>$ r) & -fura & -gura (t>r) \\
LL-devoicing & -teet- & -teete & -taru & - & -kura \\
Final form & -teeta & -teete & -taru & -fura ${ }^{13}$ & -kura \\
Variety & $\mathrm{B}, \mathrm{K}^{14}$ & $\mathrm{~B}, \mathrm{~K}, \mathrm{~W}$, & $\mathrm{B}, \mathrm{K}, \mathrm{W}$, & $\mathrm{B}, \mathrm{K}, \mathrm{W}, \mathrm{K}^{17}$ & Id, Is, T \\
& & $\mathrm{NyB}, \mathrm{K}, \mathrm{Is}^{15}$ & $\mathrm{~K}$ & \\
\end{tabular}

*k as a conditioning consonant

The examples that show $* \mathrm{k}$ as a conditioning consonant are found in numbers $10,14,21,31$, and 64. In Logooli, ${ }^{*} \mathrm{k}$ as a conditioning consonant results in ${ }^{*} \mathrm{p}$ $>\beta, *_{\mathrm{t}}>\mathrm{d}$ and ${ }^{\mathrm{k}} \mathrm{k}>\mathrm{g}-$

The results for ${ }^{*} \mathrm{k}$ as a conditioning consonant in Xaayo, Marachi and Saamia indicate $* \mathrm{p}>\beta,{ }_{\mathrm{t}}>\mathrm{d}$ and ${ }^{*} \mathrm{k}>\mathrm{k}$. However, the example used in the following table shows $* p>\varnothing$. This is the only available example that shows a sequence of stop consonants but the majority of the data shows * $p>\beta$. There is only one example for $* \mathrm{k}>\mathrm{k}$, and so the generalization made is based on 
this example. The derivation for $* \mathrm{k}>\mathrm{k}$ in Xaayo, Marachi and Saamia is shown in (a).

(a) Derivation for the form *-kuuku in Xaayo, Marachi and Saamia

\begin{tabular}{ll}
\hline PB & $*$-kuuku \\
\hline DL & -guuku \\
\hline LL-spirantization & -guuxu $(\mathrm{k}>\mathrm{x})$ \\
\hline LL-devoicing & -kuuxu \\
\hline Final form & kuuxu \\
\hline
\end{tabular}

Varieties in category $\mathrm{C}$ namely, Bukusu, Kabras, Wanga, NyalaB, Kisa, Idaxo, Isuxa and Tiriki show the following results with ${ }^{*} \mathrm{k}$ as a conditioning consonant: $* \mathrm{p}>\beta,{ }^{*}>\mathrm{t}$, and ${ }^{*} \mathrm{k}>\mathrm{k}$. The derivation for $*_{\mathrm{k}}>\mathrm{k}$ in these varieties is shown in (29) and for $*_{t}>t$, see examples in (27). Kabras and Wanga are omitted in (b) because no equivalent forms for the Proto-Bantu form *kuuku were elicited.

(b)Derivation for the form *-kuuku in category C: Bukusu, NyalaB, Kisa, Idaxo, Isuxa, Tiriki

\begin{tabular}{ll}
\hline PB & *-kuuku \\
\hline DL & -guuku \\
\hline LL-spirantization & -guuxu \\
\hline LL-devoicing & -kuuxu \\
\hline Final form & -kuuxu \\
\hline Variety & B, NyB, K, Id, Is, T
\end{tabular}

In this case, category B and C languages behave identically.

Summary of Dahl's Law and the Luyia Law

A summary chart representing how Dahl's Law operated in Luyia is illustrated next.

Dahl's Law in Luyia

\begin{tabular}{ll}
\hline Bukusu & \\
\hline Kabras & \\
\hline Wanga & \\
\hline Nyala B & Xaayo \\
\hline Kisa & Marachi \\
\hline Idaxo & Saamia \\
\hline Isuxa & Active DL and DL traces Active DL \\
\hline Tiriki & \\
\hline DL traces
\end{tabular}




\section{Kisembe}

This is followed by a chart illustrating the Luyia varieties that attested the Luyia Law.

The Luyia Law

\begin{tabular}{ll}
\hline Bukusu \\
\hline Kabras \\
\hline Wanga \\
\hline Nyala B \\
\hline Kisa \\
\hline Idaxo & \\
\hline Isuxa & \\
\hline Tiriki & \\
\hline Xaayo & Saamia \\
\hline Marachi & Logooli \\
\hline Attested the Luyia Law & Luyia Law not uniform No Luyia Law \\
\hline
\end{tabular}

\section{SUMMARY}

In Logooli (E41) all Dahl's Law reflexes are complete, which is suggestive of noninterference from other languages because of its possible former geographical physical isolation from non-Luyia languages. Xaayo, Marachi and Saamia have both active and Dahl's Law traces. Based on the geographical representation of these varieties, there is a large lump of nonLuyia speaking territory (the Luo) between Logooli and Xaayo, Marachi and Saamia. The active nature of the process in the three varieties can possibly be explained from the fact that Logooli and Xaayo, Marachi and Saamia were once contiguous before the Luo intruded, or maybe Xaayo, Marachi and Saamia speakers at some point in time moved west from Logooli.

The existence of a few active Dahl's Law reflexes in Idaxo and Tiriki indicates that at one time Dahl's Law was active in these varieties. There are two possible explanations for this. Nurse (1999) and Schadeberg (1995) explain how multilingualism due to areal contact played a role in the spread of Bantu Spirantization in many Bantu languages, and a similar analysis can be used to explain the existence of the few forms of Dahl's Law in Idaxo and Tiriki. The movement of people from one place to another and especially those within the neighboring varieties that attested Dahl's Law, such as Xaayo, Marachi and Saamia on the west and Logooli on the east, may have contributed to the spread of a few words with Dahl's Law to appear in Idaxo and Tiriki. Alternatively, it is possible that Dahl's Law operated throughout Luyia because varieties inherited it from Proto-Luyia.

We conclude therefore, that Dahl' s Law was active in Logooli, while Xaayo, Marachi and Saamia attest active Dahl's Law and also show traces of the process. The rest of the Luyia varieties have Dahl's Law traces. Because Xaayo, Marachi and Saamia behave the same way (with $p$ and $t$ as the only affected consonants), they are best represented as a subgroup using a phonological isogloss, as opposed to being classified with Logooli under southern Luyia where Dahl's Law affects all the voiceless stops $\mathrm{p}, \mathrm{t}$ and $\mathrm{k}$. 
Thus, Logooli is represented with another isogloss and the remaining varieties namely, Bukusu, Kabras, Wanga, Nyala B, Kisa, Idaxo, Isuxa and Tiriki, are grouped together by a third isogloss. But the general conclusion here holds that all of Luyia attested Dahl's Law. A new subdivision based on the results of Dahl's Law with the phonological isoglosses drawn is shown in Map 2.

Concerning the Luyia Law derivations, we conclude that the devoicing of the voiced stops $\mathrm{d}>\mathrm{t}$ and $\mathrm{g}>\mathrm{k}$ occurs in all of Luyia except Logooli. However, the devoicing of $\mathrm{d}>\mathrm{t}$ alone occurs in all of Luyia, except Logooli and category B varieties namely: Xaayo, Marachi and Saamia. Therefore an isogloss (dotted) drawn separates Logooli, Xaayo, Marachi and Saamia from the rest of Luyia. See Map 3.

Results of the other part of the Luyia Law-Spirantization show that plenition ( $p>y / w / h / \varnothing$ is not specific to Luyia. P-lenition occurs across Luyia including Logooli, and ao other Bantu languages. However, the spirantization of $\mathrm{t}>\mathrm{r}>\mathrm{r}$ occurs across Luyia except Logooli and Saamia, while $\mathrm{k}>\mathrm{x}$ occurs across Luyia except Logooli. An isogloss drawn in Map 4 separates Logooli from the rest of Luyia for $\mathrm{k}>\mathrm{x}$, and second isogloss (dotted) drawn separates Logooli and Saamia from the rest of Luyia for $t>r$.

\section{CONCLUSION}

Results for Dahl 's Law group the dialect area as one since all of Luyia attested Dahl's Law irrespective of the different treatment of Dahl's Law by the different varieties as evidenced; where Logooli attests active Dahl's Law, Xaayo, Saamia and Marachi show both active Dahl's Law and Dahl's Law traces, and the remaining varieties show Dahl's Law traces. Therefore, all Luyia underwent Dahl's Law, but Dahl's Law does not define Luyia uniquely, because it also occurred in nearby languages.

The Luyia Law on the other hand, separates Logooli and Saamia from the rest of Luyia. Logooli does not undergo the Luyia Law. Based on the word count, Logooli has more forms for $*_{\mathrm{g}}>\mathrm{g}$, while a majority of the varieties that attest the Luyia Law have most words with ${ }^{*} \mathrm{~g}>\mathrm{k}$. For ${ }^{*} \mathrm{k}>\mathrm{x}$, Logooli has a majority of the words with ${ }^{*} \mathrm{k}>\mathrm{k},{ }^{*} \mathrm{t}>\mathrm{t},{ }^{*} \mathrm{~d}>1,{ }^{*} \mathrm{p}>\mathrm{h}$, and ${ }^{*} \mathrm{~b}$ $>\beta$. This is a clear indication that Logooli does not undergo the Luyia Law. The Luyia Law in Saamia is not uniform. Saamia shows the Luyia Law for ${ }^{*} \mathrm{p},{ }^{*} \mathrm{k}$ and ${ }^{*} \mathrm{~g}$, but not for ${ }^{*} \mathrm{t}$ and ${ }^{*}$. Saamia has ${ }^{*} \mathrm{p}>\varnothing / \beta .{ }^{*} \mathrm{p}>\beta$ is as a result of Dahl's Law. A majority of the words in Saamia have $* t>t$ which is not the Luyia Law. Fewer words have $*_{t}>d$, and even fewer have $*_{t}>r$ and finally ${ }^{*} \mathrm{t}>1$. ${ }^{*} \mathrm{k}>\mathrm{x}$ forms the majority, fewer words have ${ }^{*} \mathrm{k}>\mathrm{g}$ and $\mathrm{k}>\mathrm{k} .{ }^{*} \mathrm{~g}>\mathrm{k}$ is the majority, with fewer words having $* \mathrm{~g}>\mathrm{g}$, and finally, ${ }^{*} \mathrm{~d}$ from Dahl's Law remains d. Thus, the Luyia Law defines Luyia in the north but not in the south.

Out of all this, we conclude that Saamia shows the Luyia Law for *p, *k and $*_{\mathrm{g}}$, but not for $*_{\mathrm{t}} / \mathrm{d}$. So the Luyia Law is not uniform in Saamia. Based 
on the statistics of the rest of the varieties, the Luyia Law affecting * $\mathrm{k}$ is first because it affects most of the words, as opposed to fewer words that affect *g, and $*$ d. Saamia doesn't have the Luyia Law affecting *d. Therefore, we cannot conclude that the Luyia Law defines Luyia linguistically because if we do so, then Logooli will be left out, while Saamia may or may not be included because the Luyia Law is not uniform. In conclusion therefore, what do northern and southern Luyia share uniquely? None of the two processes discussed defines Luyia uniquely.

\section{LIST OF ABBREVIATIONS}

PB Proto-Bantu

PL Proto-Luyia

NEV North East Victoria

BS Bantu Spirantization

DL Dahl's Law

LL Luyia Law

Ptn position

G Ganda

B Bukusu

K Kabras

W Wanga

X Xaayo

M Marachi

S Saamia

NyB Nyala B

Id Idaxo

Is Isuxa

T Tiriki

$\mathrm{K}$ Kisa

L Logooli

$\mathrm{Gu}$ Gusi

\section{REFERENCES}

Angogo, Rachel M. 1980. Linguistic and attitudinal factors in the maintenance of Luyia group identity. $\mathrm{PhD}$ dissertation. University of Texas at Austin.

Anttila, Raimo. 1972. An introduction to historical and comparative linguistics. New York: Macmillan Publishing Company.

Bennett, Patrick R. 1973. A phonologic history of North-East Victoria Bantu. (Unpublished MS.)

Bennett, Patrick R. 1976. Dahl's Law in Thagicu. African Language Studies. 8: $127-159$.

Bickmore, Lee S. 1998. Metathesis and Dahl's Law in EkeGusii. Studies in the Linguistic Sciences. 28.8: 149-167. 
Brown, Gillian. 1968. Phonological rules and dialect variation: a study of the phonology ofLumasaba. Cambridge: Cambridge University Press.

Chambers, Jack K and Peter Trudgill. 1980. Dialectology. Cambridge: Cambridge University Press.

Davy, Jim and Derek Nurse. 1982. Synchronic versions of Dahl's Law: the multiple applications of a phonological assimilation rule. Journal of African Languages and Linguistics. 4: 157-195.

Guthrie, Malcom. 1967-71. Comparative Bantu . Farnborough: Gregg International Publishers Ltd.

Grimes, Barbara F. 2000. A computerized ethnologue for languages of the world, 1.3th edition. Dallas, Texas: Summer Institute of Linguistics. Access date: 1st February 2002. www.sil.org/ethnologue/

Hinnebusch, Thomas J. and Derek Nurse. 1981. Spirantization in Chaga. Sprache und Geschichte in Afrika, Hamburg: Helmut Buske Verlag. 3: 51-78.

Hock, Hans and Brian D. Joseph. 1996.Language history, language change, and language relationship: an introduction to historical and comparative linguistics. New York: Mouton de Gruyter.

Hyman, Larry M. A computerized database for theoretical and historical Bantu phonology and morphology $1967 . \quad$ Department of Linguistics, University of California, Berkeley, CBOLD Grant. Access date: $20^{\text {th }} \quad$ January 2004. http://bantu.berkeley.edu/CBOLDFTP/CBOLDData/Ganda.Snoxall1967.

Hyman, Larry M. 1976. Phonologization. In Alphonse Juilland (ed.). Linguistic Studies offered to Joseph Greenberg. Saratoga, California: Anma Libri, 407-418.

Itebete, Peter. 1974. Language standardization in western Kenya: the Luyia experiment. In W. H. Whiteley (ed.). Language in Kenya. Nairobi: Oxford University Press, 87-114.

Kisembe, Lynn. 2001. An analysis of the diachronic phonological processes in Bukusu: Bantu Spirantization, Dahl's Law and the Luyia Law. Memorial University of Newfoundland. (Unpublished MS.).

Masele, Balla. 2002. The linguistic history ofSisuumbwa, Kisukuma and Kinyamweezi in Bantu Zone F. Memorial University of Newfoundland. (Unpublished $\mathrm{PhD}$ thesis.).

Meinhof, Carl. 1932. Introduction to the phonology of Bantu languages: being the English translation of "GrundriB einer Lautlehre der Bantusprachen", translated, revised and enlarged in collaboration with the author and Dr Alice Werner by N.J.v. Warmelo. Berlin: Dietrich Reimer, Ernst Vohsen.

Moehlig, Wilhelm J. G. 1981. Stratification in the history of the Bantu languages. Sprache und Geschichte in Afrika, Beiheft 3: 251-319.

Mould, Martin. 1981. Greater Luyia. In H. Thomas, D. Nurse and M. Mould (eds.). Studies in the Classification of Eastern Bantu Languages. 
Sprache und Geschichte in Afrika, Beiheft 3. Hamburg: Helmut Buske Verlag, 181-261.

Nurse, Derek. 1979. Classification of the Chaga dialects: language and history on Kilimanjaro, the Taita hills, and the Pare mountains, with 24 tables and 3 maps. Hamburg: Helmut Buske Verlag.

Nurse, Derek. 1981. Chaga/Taita. In H. Thomas, D. Nurse and M. Mould (eds. Jjtudies in the Classification of Eastern Bantu Languages. Sprache und Geschichte in Afrika, Beiheft 3. Hamburg: Helmut Buske Verlag, 127-180.

Nurse, Derek. 1987. Towards a typology of diachronic linguistic change in Bantu languages. Journal of the Atlantic Provinces Linguistic Association. 9: 100-122.

Nurse, Derek. 1999. Towards a historical classification of East African Bantu languages. InJ-M. Hombert and L. M. Hyman (Q\&s.)Bantu historical linguistics: theoretical and empirical Perspectives. Stanford, California: Center for the Study of Language and Information Publications, 1-41.

Nurse, Derek and Thomas J. Hinnebusch. 1993. Swahili and Sabaki: a linguistic history. Berkeley: University of California Press.

Nurse, Derek and Gerard Philippson. 1980. The Bantu languages of East Africa: A lexicostatistical survey. In E.G. Polome and C. P. Hill (eds.). Language in Tanzania. Oxford: Oxford University Press, 2667.

Schadeberg, Thilo C. 1995. Spirantization and the 7-to-5 vowel merger in Bantu. In Dominicy, Marc and Didier Demolin (eds.). Journal of Linguistics, Issue devoted to sound change. 9:73-84.

Zoll, Cheryl. 1995. Consonant mutation in Bantu: a squib. Linguistic Inquiry. 26. 536-

545. 